\title{
Effects of nano-sized titanium dioxide powder and ultraviolet light on superficial veins in a rabbit model
}

\author{
Fatih Ada, ${ }^{1, A-D}$, Ferit Kasimzade ${ }^{2, C-E}$, Ali Sefa Mendili, ${ }^{3, B}$, , Hasan Gocmez $z^{4, E, F}$ \\ ${ }^{1}$ Department of Cardiovascular Surgery, School of Medicine, Sivas Cumhuriyet University, \\ 2 Department of Cardiovascular Surgery, Ministry of Health Ankara City Hospital, Turkey \\ ${ }^{3}$ Faculty of Veterinary Medicine, Erciyes University, Kayseri, Turkey \\ ${ }^{4}$ Faculty of Engineering, Kütahya Dumlupınar University, Turkey \\ A - research concept and design; $\mathrm{B}$ - collection and/or assembly of data; $\mathrm{C}$ - data analysis and interpretation; \\ $D$ - writing the article; $E$ - critical revision of the article; $F$ - final approval of the article
}

Address for correspondence

Fatih Ada

E-mail: drfatihada@gmail.com

\section{Funding sources}

None declared

Conflict of interest

None declared

Received on April 22, 2021

Reviewed on July 1,2021

Accepted on August 21, 2021

Published online on 0ctober 12, 2021

\begin{abstract}
Background. Titanium dioxide $\left(\mathrm{TiO}_{2}\right)$ is widely used in many fields such as food, cosmetics, and paper industries. Studies on the photocatalytic properties of $\mathrm{TiO}_{2}$ on living tissue are limited.

Objectives. To examine the histopathological effects of $\mathrm{TiO}_{2}$ solution on the marginal veins of rabbit ears under ultraviolet (UV) light.

Materials and methods. In this study, 4 groups of rabbits ( 8 rabbits per group) were used: the $1^{\text {st }}$ group was the control group, the $2^{\text {nd }}$ group received $20 \%$ of nano- $-\mathrm{IO}_{2}$ only, the $3^{\text {rd }}$ group received UV light only, and the $4^{\text {th }}$ group received nano- $\mathrm{Ti}_{2}$ and $\mathrm{UV}$ light, simultaneously. The study lasted for 14 days and samples were taken from the marginal ear vein on the $15^{\text {th }}$ day.

Results. The ear tissues of rabbits in the control and $\mathrm{Ti}_{2}$ groups showed a normal histological appearance. In the UV group, the results showed severe chronic inflammation due to mononuclear cells around the hair follicles and perivascular areas. However, these findings decreased in the UV/nano- $\mathrm{Ti} \mathrm{O}_{2}$ group.

Conclusions. The method applied in this study can be used in the treatment of telangiectasia in the future. However, this study investigating the effects of nano-- $\mathrm{IiO}_{2}$ on vascular structures under UV light had a predominantly histological and observational nature. Further studies involving genetic, cytogenetic, biochemical, histochemical, and immunohistochemical analyses need to be performed to test the theories we proposed.
\end{abstract}

Key words: animal model, titanium dioxide, vein, nano-TiO2, ultraviolet light

Cite as

Ada F, Kasimzade F, Mendil AS, Gocmez H. Effects of nanosized titanium dioxide powder and ultraviolet light on superficial veins in a rabbit model. Adv Clin Exp Med. 2021;30(12):1255-1262. doi:10.17219/acem/141501

DOI

10.17219/acem/141501

Copyright

Copyright by Author(s)

This is an article distributed under the terms of the

Creative Commons Attribution 3.0 Unported (CC BY 3.0)

(https://creativecommons.org/licenses/by/3.0/) 


\section{Background}

Titanium dioxide $\left(\mathrm{TiO}_{2}\right)$, also known as titania, is widely used in many fields such as paints, cosmetics, food products, and pharmaceuticals. With the discovery of the photocatalytic activity of $\mathrm{TiO}_{2}$, the use of this material has expanded. ${ }^{1}$ Titanium dioxide can be found in many crystalline structures in nature, but it has 2 basic structures: the rutile and anatase polymorphic phases. Titania also has many favorable properties such as semiconductivity, non-toxicity, white color, low cost, chemical stability, and photocatalytic activity.

The nano- $\mathrm{TiO}_{2}$ electron band gap is higher than $3 \mathrm{eV}$ and has a high absorption in the ultraviolet (UV) region. However, due to its strong optical and biological properties, it can be used in UV light protection applications. Many studies have been conducted to examine the photocatalytic activity of $\mathrm{TiO}_{2}$.

Photocatalysts can be defined as semiconductors that become active when interacting with light, forming strongly oxidized or reductive active surfaces. Sunlight promotes the purification of water systems in nature, such as rivers, streams, lakes, and pools. The sunrays initiate the breakdown of large organic molecules into smaller, simpler molecules. This breakdown reaction eventually results in the formation of carbon dioxide, water and other molecular products. The results of laboratory studies in the early 1980 s indicated that semiconductors accelerated this natural purification process induced by sunlight. ${ }^{2}$

High-efficiency photocatalysts under UV light also have high efficiency under visible light when various methods are applied. The S-doped $\mathrm{TiO}_{2}$ has high photocatalytic activity under visible light. ${ }^{3}$ For example, $\mathrm{S}$-doped $\mathrm{TiO}_{2}$ has high efficiency at a $500 \mathrm{~nm}$ wavelength, while $\mathrm{Ru}$-doped $\mathrm{TiO}_{2}$ has high photocatalytic activity at a $440 \mathrm{~nm}$ wavelength. ${ }^{3}$

Studies on the photocatalytic properties of $\mathrm{TiO}_{2}$ on living tissue are limited. To address this research gap, this study investigated the histopathological effects of $\mathrm{TiO}_{2}$ on the superficial veins of rabbit ears under UV light by utilizing its photocatalytic properties.

\section{Objectives}

Photocatalysts, which are commonly used for cleaning the environment, water and air, are now being used in different fields. Watanabe et al. evaluated the photocatalytic activity of nano-sized $\mathrm{TiO}_{2}$ in an artificial skin model. ${ }^{4}$ They sequentially measured the $\mathrm{CO}_{2}$ levels on artificial skin with the addition of nano-sized $\mathrm{TiO}_{2}$, and found an increase in a mbient $\mathrm{CO}_{2}$ level with photocatalytic activity. Shen et al. encapsulated $\mathrm{TiO}_{2}$ with zeolite to increase its photocatalytic activity in sunscreens, and found that the harmful effects of UV light were minimized. ${ }^{5}$

The present study aimed to investigate the effects of nano-sized $\mathrm{TiO}_{2}$ on superficial veins under UV light with a $368 \mathrm{~nm}$ wavelength in a rabbit model.

\section{Materials and methods}

This study was approved by the Local Ethics Committee of Sivas Cumhuriyet University (Sivas, Turkey; approval No. 65202830-050.04.04-62). All procedures were carried out at Sivas Cumhuriyet University Laboratory of Experimental Animals in accordance with the local rules of care and use of experimental animals.

The study was conducted as a controlled randomized animal experiment. This study employed a total of 8 male and female New Zealand white rabbits from 6 to 8 months of age. The rabbits weighed between $3.2 \mathrm{~kg}$ and $3.5 \mathrm{~kg}$ for males and between $2.75 \mathrm{~kg}$ and $3 \mathrm{~kg}$ for females. All animals were fed a standard laboratory diet with free access to water. The rabbits were housed with 1 animal in each cage. Rabbits that were able to perform their normal activities in the cages were kept in rooms with a temperature of $22 \pm 2^{\circ} \mathrm{C}$, a humidity level between $50 \%$ and $70 \%$, and a $12 \mathrm{~h}$ day/12 h night cycle. All animals were kept under observation for 1 day to determine whether they were healthy before the experiments. Healthy animals without any problems were included in the study.

The rabbits were divided into the following 4 groups (8 rabbits per group; Table 1 ):

- group 1 - control group: no treatment was performed;

- group $2-20 \%$ nano- $\mathrm{TiO}_{2}$ group: $0.2 \mathrm{~mL}$ of nano-sized $20 \% \mathrm{TiO}_{2}$ solution was topically applied to the visible marginal vein of the right ears of the rabbits every day. No other procedure was performed;

- group 3 - UV group: rabbits were exposed to ultraviolet A (UVA) light at a wavelength range of $368 \mathrm{~nm}$ for $12 \mathrm{~h}$ a day, at a distance of approx. $150 \mathrm{~cm}$. No other procedure was performed;

Table 1. Experimental groups and their characteristics

\begin{tabular}{|l|c|c|c|c|}
\hline \multicolumn{1}{|c|}{ Groups } & Procedure & Method of procedure & Procedure modality and duration \\
\hline Group 1 & control group & - & - \\
\hline Group 2 & $20 \%$ nano-TiO & topical & daily \\
\hline Group 3 & UV & $12 \mathrm{~h}$ & $12 \mathrm{~h}$ a day, at a distance of $150 \mathrm{~cm}$ & at a wavelength of $368 \mathrm{~nm}$ UV \\
\hline Group 4 & $20 \%$ nano- $\mathrm{TiO}_{2}+$ UV & topical + UV & $12 \mathrm{~h}$ a day, at a distance of $150 \mathrm{~cm}$ & at a wavelength of $368 \mathrm{~nm}$ UV \\
\hline
\end{tabular}

UV - ultraviolet light; $\mathrm{TiO}_{2}$ - titanium dioxide. 


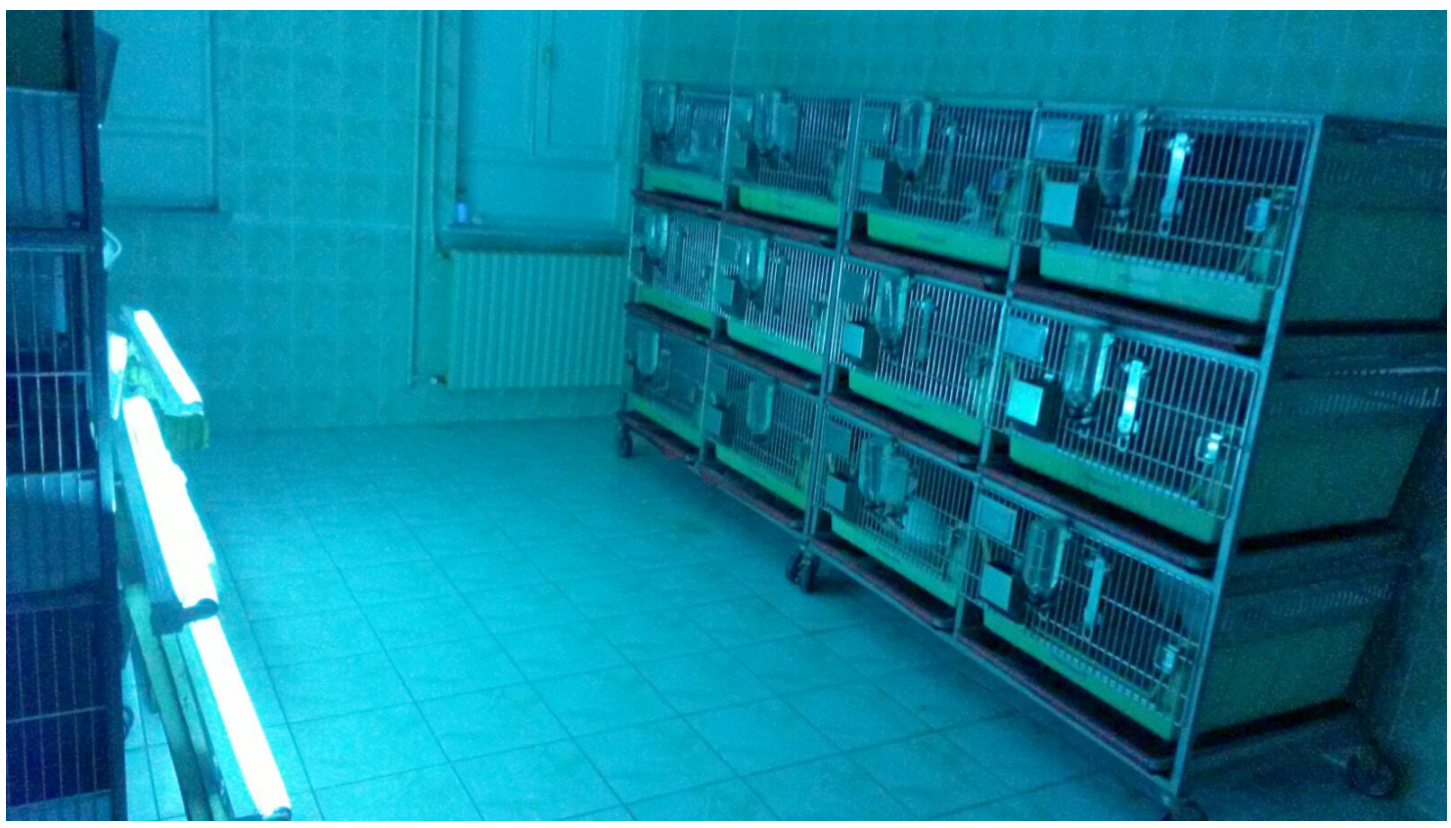

Fig. 1. Ultraviolet light was applied at a distance of $150 \mathrm{~cm}$. Each rabbit was kept in a single cage
- group 4-20\% nano- $\mathrm{TiO}_{2}$ and UV light group: $0.2 \mathrm{~mL}$ of nano-sized $20 \% \mathrm{TiO}_{2}$ solution was topically applied to the visible marginal vein of the right ears of the rabbits every day. Simultaneously, UVA at a wavelength of $368 \mathrm{~nm}$ at a distance of $150 \mathrm{~cm}$ was applied for $12 \mathrm{~h}$ a day.

The procedures were performed for 14 days (Fig. 1). On the $15^{\text {th }}$ day, punch biopsies were taken from the marginal vein under local anesthesia from all groups. The samples were then examined histologically.

For the nano- $\mathrm{TiO}_{2}, 20 \mathrm{~nm} \mathrm{TiO}_{2}$ powder with the tradename Degussa p25 (Nanoshel LLC, Wilmington, USA) was used. The UVA light sources were Sylvania brand UV lamps (Erlangen, Germany), measuring 40W/4FT/T12/BL368 with a wavelength of $368 \mathrm{~nm}$. No treatment or euthanasia was performed on the animals at the end of the study.

\section{Histopathological examination}

The ear tissue samples from the rabbits were placed in $10 \%$ buffered formalin solution. The samples were then subjected to routine follow-up procedures and embedded in paraffin blocks. Next, the $5-\mu \mathrm{m}$ sections taken from the blocks were stained with hematoxylin and eosin (H\&E) to assess histopathological changes. Sections were examined under a light microscope and semi-quantitatively scored as negative $(-)$, mild $(+)$, moderate $(++)$, or severe $(+++)$ for chronic inflammation. The increase in macrophage and lymphocyte density in the tissue was used as a chronic inflammation marker. We evaluated the vascular samples and scored them according to the histopathological scale described by Kuwahara et al. ${ }^{6}$

\section{Statistical analyses}

Microsoft Excel 2010 (Microsoft Corp., Redmond, USA) and SPSS v. 16.0 (SPSS Inc., Chicago, USA) were used to perform the statistical analysis. Based on an $\alpha$ of 0.05 , $\beta$ of 0.20 and $1-\beta$ of 0.80 , we decided to include 8 rabbits in each group (32 rabbits in total) and the power was calculated to be 0.8345 . Since the distribution of the data was not normal, the KruskalWallis $\mathrm{H}$ test was conducted to assess significant differences between groups. For post hoc tests of differences between groups, Dunn's post hoc test was used, because it preserves the pooled variance for the tests implied by the Kruskal-Wallis null hypothesis (Table 2). When the data violated the normality assumption (Table 3), we decided to use the nonparametric

Table 2. Statistical significance of differences between groups according to Dunn's post hoc test

\begin{tabular}{|c|c|c|c|c|}
\hline Sample 1 compared to sample 2 & Test statistic & SD error & SD test statistic & $\mathrm{p}$-value \\
\hline $20 \%$ nano- $\mathrm{TiO}_{2}$ group compared to control group & 1.063 & 4.464 & 0.238 & 0.812 \\
\hline $20 \%$ nano- $\mathrm{TiO}_{2}$-group compared to $20 \%$ nano- $\mathrm{TiO}_{2}$ and UV group & -12.687 & 4.464 & -2.842 & 0.004 \\
\hline $20 \%$ nano- $\mathrm{TiO}_{2}$-group compared to UV group & -20.000 & 4.464 & -4.480 & 0.000 \\
\hline Control group compared to $20 \%$ nano- $\mathrm{TiO}_{2}$ and UV group & -11.625 & 4.464 & -2.604 & 0.009 \\
\hline Control group compared to UV group & -18.937 & 4.464 & -4.242 & 0.000 \\
\hline $20 \%$ nano- $-\mathrm{TiO}_{2}$ and UV group compared to UV group & 7.313 & 4.464 & 1.638 & 0.101 \\
\hline
\end{tabular}

UV - ultraviolet light; SD - standard deviation; $\mathrm{TiO}_{2}$ - titanium dioxide. 
Table 3. Descriptive statistics of the treatment groups

\begin{tabular}{|l|l|c|c|}
\multicolumn{1}{|c|}{ Groups } & Mean (SD) & Median & Maximum \\
\hline Control group & $0.25(0.463)$ & 0.00 & 1 \\
\hline $20 \%$ nano- $\mathrm{TiO}_{2}$ group & $0.13(0.354)$ & 0.00 & 1 \\
\hline UV group & $2.88(0.354)$ & 3.00 & 0 \\
\hline $20 \%$ nano- $\mathrm{TiO}_{2}$ and UV group & $1.88(0.354)$ & 2.00 & 2 \\
\hline
\end{tabular}

UV - ultraviolet light; SD - standard deviation; $\mathrm{TiO}_{2}$ - titanium dioxide.

Kruskal-Wallis $\mathrm{H}$ test to compare the mean rank scores of the groups. The effect size for the test was calculated as 4.92 .

\section{Results}

Four female and 4 male rabbits were included in each experimental group; thus, there were no statistically significant differences between the groups in terms of gender ( $p>0.05)$. The results showed that the ear tissues of the rabbits in the control and nano- $\mathrm{TiO}_{2}$ groups had a normal histological appearance (Fig. 2). However, we observed the formation of severe chronic inflammation of mononuclear cells in the perivascular areas and around the hair follicles in the UV group (Table 4).

The results of the Kruskal-Wallis $\mathrm{H}$ test indicated significant differences between groups subjected to different treatment methods $\left(\chi^{2}(3)=27.835, \mathrm{p}<0.001\right)$, with mean rank scores of 9.12 for the control group, 8.06 for the $20 \%$ nano- $\mathrm{TiO}_{2}$ group, 28.06 for the UV group, and 20.75 for the group administered both $20 \%$ nano- $\mathrm{TiO}_{2}$ and $\mathrm{UV}$. Dunn's pairwise post hoc test indicated significant differences between the control group and the UV group ( $\mathrm{p}<0.001$ ), between the $20 \%$ nano- $\mathrm{TiO}_{2}$ group and the UV group ( $\mathrm{p}<0.001$ ), between the $20 \%$ nano- $\mathrm{TiO}_{2}$ group and the group administered both $20 \%$ nano- $\mathrm{TiO}_{2}$ and UV light ( $\mathrm{p}=0.004)$, and between the control group and the group administered both $20 \%$ nano- $-\mathrm{TiO}_{2}$ and UV light ( $\mathrm{p}=0.009)$. There were no other significant differences (Table 5). The histopathological changes decreased in the group that received both UV and nano$\mathrm{TiO}_{2}$. Macroscopically, the results indicated that the visibility of rabbit ear veins decreased in the $20 \%$ nano- $\mathrm{TiO}_{2}$ and UV light group (Fig. 3).
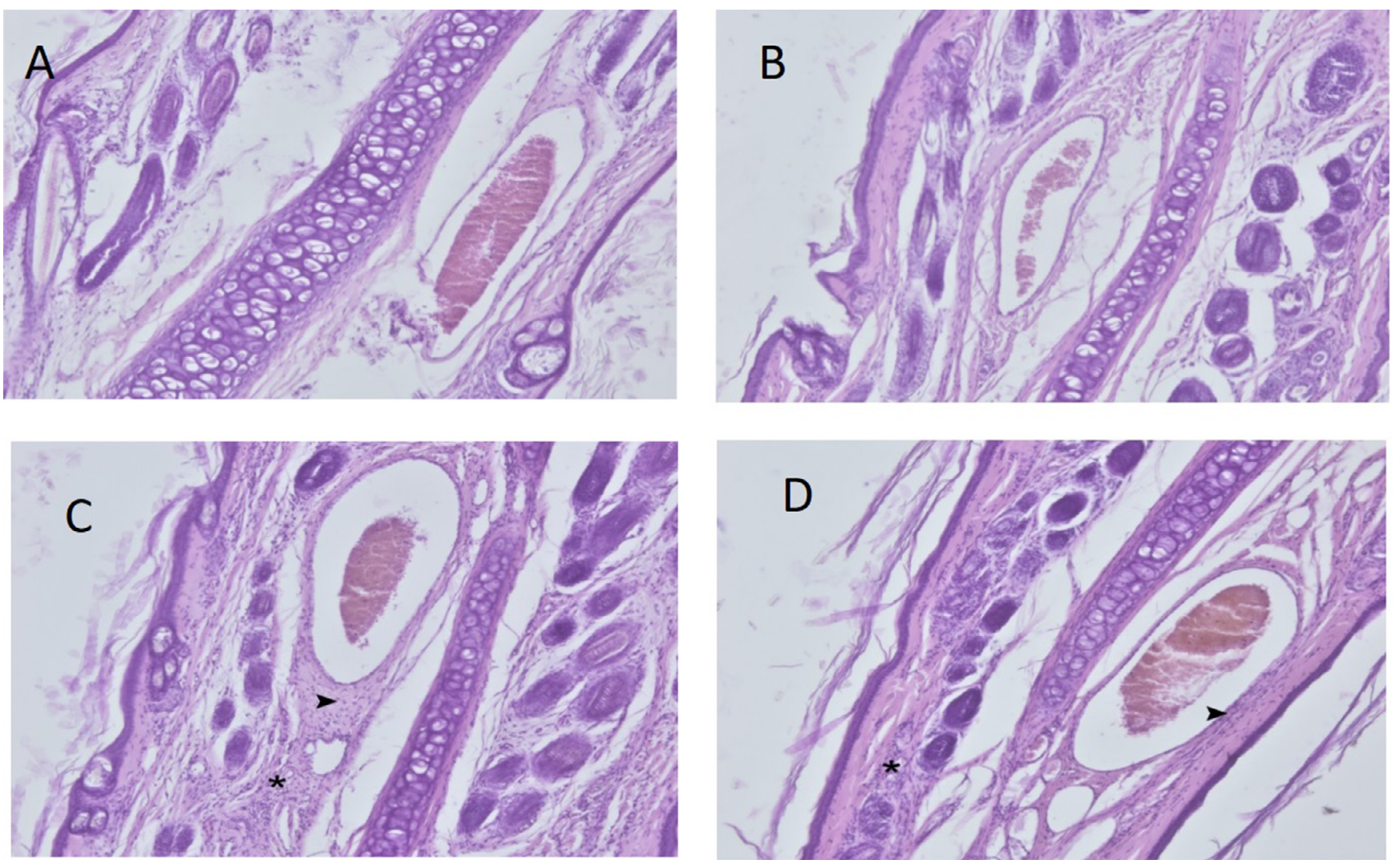

Fig. 2. A. Control group. Normal histological appearance. $\times 40$ magnification, hematoxylin and eosin $(\mathrm{H} \& \mathrm{E})$ staining; $\mathrm{B}$. Titanium dioxide (TiO 2 ) group. Normal histological appearance. $\times 40$ magnification, H\&E staining; C. Ultraviolet (UV) group. Severe mononuclear cell infiltration is present around the vein (arrowhead) and near the hair follicles $\left(^{*}\right) . \times 40$ magnification, $\mathrm{H} \& \mathrm{E}$ staining; D. Ultraviolet light $+\mathrm{TiO}_{2}$ group. Moderate mononuclear cell infiltration is present around the vessel (arrowhead) and near the hair follicles $(*) . \times 40$ magnification, H\&E staining 
Table 4. Inflammation degrees of the groups

\begin{tabular}{|l|c|c|c|}
\multicolumn{1}{|c|}{ Inflammation } & $\begin{array}{c}\text { Group 1 } \\
(\mathrm{n=8)}\end{array}$ & $\begin{array}{c}\text { Group 2 } \\
(\mathrm{n}=8)\end{array}$ & $\begin{array}{c}\text { Group 3 } \\
(\mathrm{n}=8)\end{array}$ \\
\hline Negative [\%] & 75 & 87.5 & 0 \\
\hline Mild [\%] & 25 & 12.5 & 0 \\
\hline Moderate [\%] & 0 & 0 & 12.5 \\
\hline Severe [\%] & 0 & 0 & 87.5 \\
\hline
\end{tabular}

Table 5. Kruskal-Wallis H test analysis table for all treatment groups

\begin{tabular}{|l|c|c|c|}
\multicolumn{1}{|c|}{ Groups } & Mean rank & $x^{2}$ & df \\
\hline Control group & 9.12 & 27.835 & 3 \\
\hline $20 \%$ nano- $\mathrm{TiO}_{2}$ group & 8.06 & - & - \\
\hline UV light group & 28.06 & - & - \\
\hline $20 \%$ nano- $\mathrm{TiO}_{2}$ and UV light group & 20.75 & - & - \\
\hline
\end{tabular}

UV - ultraviolet light; $\mathrm{TiO}_{2}$ - titanium dioxide; $\mathrm{df}$ - degrees of freedom.

\section{Discussion}

At present, $\mathrm{TiO}_{2}$ is widely used in many industries such as pharmaceuticals, cosmetics (especially in sunscreens), food, biomedical products, etc. Given its wide use, it is necessary to investigate the toxicological and histological effects of nano- $\mathrm{TiO}_{2}$, as well as its effects on the immune system. Fabian et al. administered titanium dioxide nanoparticles intravenously to rats and found that they did not cause any toxic effects at a $5 \mathrm{mg} / \mathrm{kg}$ dose and could be used safely at this dose. ${ }^{7}$ Warheit et al. administered $300 \mathrm{~nm}$ of titanium dioxide via inhalation in rabbits and showed that short-term exposure did not cause any lung problems. ${ }^{8}$ In the same study, they reported that $\mathrm{TiO}_{2}$ of this size had no genotoxic effect and did not cause any irritation of the skin, but reversible conjunctival redness in the eyes of rabbits was observed. In a review of the effects of nano-sized $\mathrm{TiO}_{2}$ on the lung, size, exposure time, and the amount of nano-titanium were identified as the most important risk factors. ${ }^{9}$

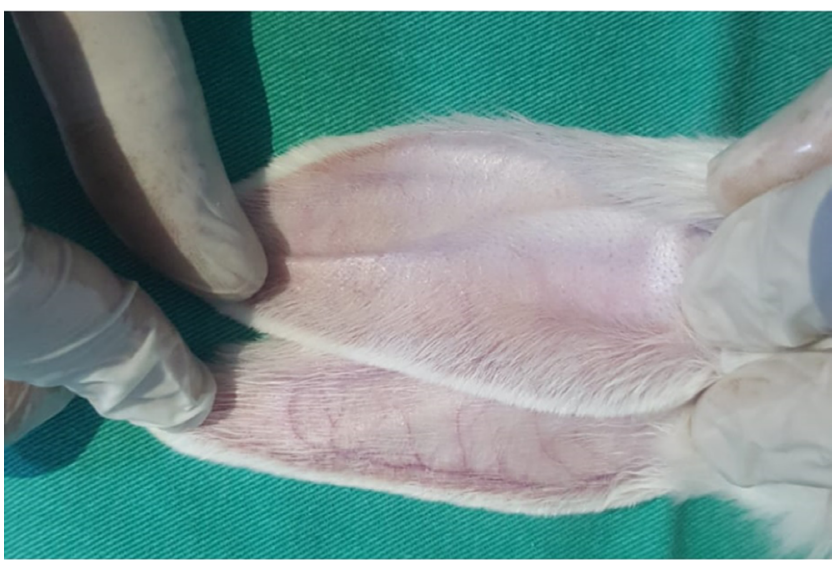

Fig. 3. On the $14^{\text {th }}$ day of the study, titanium dioxide $\left(\mathrm{TiO}_{2}\right)$ and ultraviolet (UV) light were applied to the rabbits. Titanium dioxide was applied to the upper ear, but not lower ear. Note the difference between venous structures
In a wide-ranging review, Iavicoli et al. investigated the effects of nano- $\mathrm{TiO}_{2}$ on mammals organ by organ and system by system. ${ }^{10}$ Although they discussed the effects of nano- $\mathrm{TiO}_{2}$ on many systems, they emphasized that their effects on vascular structures were not clear. However, they stated that the effects of $\mathrm{TiO}_{2}$ were directly related to the way it was administered, its dose, duration, and particle size. Tang et al. examined the relationship between administration routes and doses of $\mathrm{TiO}_{2} \cdot{ }^{11}$ They found that $\mathrm{TiO}_{2}$ with a size of $5 \mathrm{~nm}$ could be passed to the blood intratracheally; when it reached a dose of $0.8 \mathrm{mg} / \mathrm{kg}$, it could reach the lungs and kidneys and it changed liver and kidney function. However, they observed that these effects were reversible after 1 week without permanent damage.

There is a limited number of studies on the effects of $\mathrm{TiO}_{2}$ on vascular structures in the literature. In a study using porcine pulmonary artery endothelial culture, Han et al. reported that nano- $\mathrm{TiO}_{2}$ increased the inflammatory response in endothelial cells. ${ }^{12}$ They concluded that the increased inflammation response occurred via the redoxsensitive cell signaling pathway.

Montiel-Dávalos et al. conducted a study on human umbilical vein endothelial cell culture (HUVEC) and found that $\mathrm{TiO}_{2}$ inhibited the proliferation of endothelial cells and accelerated apoptotic and necrotic death. ${ }^{13}$ Alinovi et al. also conducted a study using HUVEC and found that $\mathrm{TiO}_{2}$ nanoparticles increased inflammation in endothelial cells. ${ }^{14}$ Park et al. conducted a study using a mouse endothelial cell culture line and evaluated whether the size of the nanotube affected the endothelial adhesion and apoptosis rates of $\mathrm{TiO}_{2}$ nanotubes. ${ }^{15}$ They observed more endothelial adhesion, less apoptosis, and less inflammation in $15 \mathrm{~nm}$ nanotubes. Furthermore, their results indicated an increase in inflammation and apoptosis as the size of the nanotubes increased. These findings demonstrate the importance of size in terms of the effectiveness of nano- $\mathrm{TiO}_{2}$ to be used in vascular implants. 
Ge et al. conducted a study using HUVEC and their results indicated that thin film nano- $\mathrm{TiO}_{2}$ provided laminin immobilization and an increase in endothelial adhesion. ${ }^{16}$

Ultraviolet light has been used in the treatment of skin diseases since the beginning of the $20^{\text {th }}$ century. Although the mechanism of UV light action is not clear, hypotheses that it increases cell proliferation, epidermal thickness and blood flow in cutaneous capillaries have been proposed. ${ }^{17}$ In a study that applied UV light to patients with venous ulcers, Dodd et al. concluded that UV light had no benefit in the treatment of venous ulcers. ${ }^{18}$ However, they observed that UV light increased skin oxygen permeability and inhibited normal vasoconstrictor response.

When light treatment is required in medicine, the preferred UV light wavelength is in the 300-320 $\mathrm{nm}$ range. In dermatology, psoralen ultraviolet A (PUVA) treatment for psoriasis, eczema, vitiligo, and cutaneous lymphoma is widely used. ${ }^{19}$ Although UV light has positive results when applied to appropriate patients for a certain period of time, dose and treatment, excessive exposure can lead to many adverse conditions such as skin cancer, T cell damage, immune depression, sunburn, and premature skin aging. ${ }^{20}$

Telangiectasias are enlarged venous vessels with a diameter of $0.5-1 \mathrm{~mm}$ near the skin surface. Telangiectasias are enlarged postcapillary venules located in the papillary and superficial reticular dermis with histologically complete meaning. ${ }^{21}$

Engel et al. conducted a field study with a large population in the USA and found that the rate of telangiectasia in the legs was $29-41 \%$ in women and $6-15 \%$ in men. ${ }^{22} \mathrm{Fa}$ cial telangiectasia affects tens of millions of people around the world. ${ }^{23}$ Sclerotherapy is the standard approach for the treatment of telangiectasias. Sclerosis of the telangiectatic vein is the main target in sclerotherapy. In order to achieve sclerosis, various chemical sclerosing agents are administered directly into the enlarged telangiectatic vein, resulting in the formation of a thrombosis and endothelial damage within the vein. ${ }^{24}$

Apart from sclerotherapy, many different laser treatments, such as argon ion lasers, diode lasers and intense pulsed light sources, are applied. ${ }^{25,26}$ Laser treatment was first performed in the treatment of telangiectasias in 1960 using light at a $694 \mathrm{~nm}$ wavelength, followed by different systems and wavelengths. ${ }^{27}$ The underlying logic of laser treatment in telangiectasia is to cause the loss of veins close to the skin surface by creating thermal damage to the vascular structures through the heat generated by UV light. Hemoglobin in the vessel absorbs light best at $418 \mathrm{~nm}, 542 \mathrm{~nm}$ and $577 \mathrm{~nm}$ wavelengths. ${ }^{28}$ However, the wavelengths used in the treatment of vascular lesions are usually $488 \mathrm{~nm}$ and $600 \mathrm{~nm} .^{28}$

Photocatalysts can be described as semiconductors that create a strongly oxidized environment on the surface through the effect of UV light. Therefore, photocatalysts can cause degradation in organic tissues close to the region where they are applied. Among the known semiconductor photocatalysts, $\mathrm{TiO}_{2}$ is widely used due to its high activity, high stability under lighting, nontoxic nature, and low price. Titanium dioxide performs its photocatalytic effect best under $340 \mathrm{~nm}$ wavelength light, but a wavelength range of $320-380 \mathrm{~nm}$ is also good for photocatalyst activity. ${ }^{29}$

In general, studies have demonstrated that organic cell degradation increases as the wavelength decreases. This means that at a wavelength of $280 \mathrm{~nm}$ or less, $\mathrm{TiO}_{2}$ has its maximum photocatalytic effect, leading to the degradation of DNA and RNA. ${ }^{30,31}$ Therefore, the light wavelength selected in our study was in the range of 320-380 nm. The same ultraviolet light wavelength and application methods used in previous animal experiments, as well as the dose, concentration, and routes of $\mathrm{TiO}_{2}$ administration were applied in the current study. ${ }^{32,33}$ What distinguishes this study from the other studies is that we investigated the effects of $\mathrm{TiO}_{2}$ and UV light on vascular structures simultaneously.

Photodynamic therapy, especially in dermatology and plastic surgery, is used effectively and widely for the treatment of many dermatological diseases in the form of a combination of light and various creams applied to the skin. The main principle of creams with methyl aminolevulinate as the active ingredient is to be absorbed by the skin and subcutaneous tissue, and to provide local apoptosis with the effect of light. In fact, Galvão found that telangiectasias on the face were not visible after photodynamic therapy in a patient with facial actinic keratosis. ${ }^{34}$

Photodynamic therapy consists of 3 main elements: a photosensitive material, a light source and oxygen. When these 3 factors are combined effectively, they can be applied for the successful treatment of many skin lesions. In photodynamic therapy, the therapeutic effect is achieved by a slight activation of a light-sensitive substance, and reactive oxygen intermediates are formed in the presence of oxygen. These intermediates irreversibly oxidize the essential cellular components that cause apoptosis and necrosis, thereby providing the treatment of lesions on the skin. ${ }^{35}$ Essentially, our study has shown similar results to photodynamic therapy. In this sense, the study demonstrated that substances with photocatalytic activation may be an appropriate choice for this treatment.

\section{Limitations}

The method applied in the present study could be used in the treatment of telangiectasia in the future. However, our study has a predominantly histological and observational nature. Further studies involving genetic, cytogenetic, biochemical, histochemical, and immunohistochemical analyses are needed to test the theories described above.

\section{Conclusion}

The results of this study revealed that nano- $\mathrm{TiO}_{2}$ protected the skin and the main vascular structures close to the skin from the harmful effects of UV light. 
Furthermore, this study determined that telangiectatic structures close to the skin were not observed in the UV and nano- $\mathrm{TiO}_{2}$ group.

Several theories were put forward regarding the absence of telangiectatic structures in the rabbit ear on macroscopic observation. The $1^{\text {st }}$ is that nano- $\mathrm{TiO}_{2}$ and UV light induced apoptosis in telangiectatic structures, just as in photodynamic therapy. The $2^{\text {nd }}$ is that thermal damage was caused by heating during the photocatalytic activation of nano- $\mathrm{TiO}_{2}$. The $3^{\text {rd }}$ theory is that collagen tissue deposited under the epidermis compressed the telangiectatic veins or precipitated them towards the dermis. The $4^{\text {th }}$ is damage of hemoglobin in the telangiectatic vein. The $5^{\text {th }}$ is selective photothermolysis that led to panendothelial obliteration. Any combination of these theories, or some other mechanism of action, may have led to these results.

\section{ORCID iDs}

Fatih Ada (1) https://orcid.org/0000-0002-6953-5906

Ferit Kasimzade (1) https://orcid.org/0000-0003-3646-3181

Ali Sefa Mendil (1) https://orcid.org/0000-0003-2722-3290

Hasan Gocmez (1) https://orcid.org/0000-0003-3748-0311

\section{References}

1. Şam ED, Ürgen $\mathrm{M}$, Tepehan FZ. $\mathrm{TiO}_{2}$ fotokatalistleri. ITÜ Dergisi/D Mühendislik. 2007;6(5-6):81-92. http://itudergi.itu.edu.tr/index.php/ itudergisi_d/article/viewFile/395/337. Accessed November 1, 2020.

2. Ochiai T, Fujishima A. Design and optimization of photocatalytic water purification reactors. In: Pichat P, ed. Photocatalysis Water Purification: From Fundamentals to Recent Applications. Weinheim, Germany: Wiley-VCH; 2013:361. doi:10.1002/9783527645404.ch14

3. Ohno T, Akiyoshi M, Umebayashi T, et al. Preparation of S-doped $\mathrm{TiO}_{2}$ photocatalysts and their photocatalytic activities under visible light. Appl Catal A Gen. 2004;265(1):115-121. doi:10.1016/j.apcata.2004.01.007

4. Watanabe E, Fukaya M, Nishizawa K, Miki T, Taoda H. Test method for skin damage of titania photocatalyst nanoparticles in vitro. Mater Sci Forum. 2008;569:9-12. doi:10.4028/www.scientific.net/MSF.569.9

5. Shen B, Scaiano JC, English AM. Zeolite encapsulation decreases $\mathrm{TiO}_{2-}$ photosensitized ROS generation in cultured human skin fibroblasts. Photochem Photobiol. 2006;82(1):5-12. doi:10.1562/2005-05-29-RA-551

6. Kuwahara T, Asanami S, Kubo S. Experimental infusion phlebitis:Tolerance osmolality of peripheral venous endothelial cells. Nutrition. 1998;14(6):496-501. doi:10.1016/s0899-9007(98)00037-9

7. Fabian E, Landsiedel R, Ma-Hock L, Wiench K, Wohlleben W, van Ravenzwaay $B$. Tissue distribution and toxicity of intravenously administered titanium dioxide nanoparticles in rats. Arch Toxicol. 2008; 82(3):151-157. doi:10.1007/s00204-007-0253-y

8. Warheit DB, Hoke RA, Finlay C, Donner EM, Reed KL, Sayes CM. Development of a base set of toxicity tests using ultrafine $\mathrm{TiO}_{2}$ particles as a component of nanoparticle risk management. Toxicol Lett. 2007; 171(3):99-110. doi:10.1016/j.toxlet.2007.04.008

9. Warheit DB. How to measure hazards/risks following exposures to nanoscale or pigment-grade titanium dioxide particles. Toxicol Lett. 2013;220(2):193-204. doi:10.1016/j.toxlet.2013.04.002

10. Iavicoli I, Leso V, Fontana L, Bergamaschi A. Toxicological effects of titanium dioxide nanoparticles: A review of in vitro mammalian studies. Eur Rev Med Pharmacol Sci. 2011;15(5):481-508. doi:10.1155/ 2012/964381

11. Tang $M$, Zhang $T$, Xue $Y$, et al. Dose dependent in vivo metabolic characteristics of titanium dioxide nanoparticles. J Nanosci Nanotechnol. 2010;10(12):8575-8583. doi:10.1166/jnn.2010.2482

12. Han SG, Newsome B, Hennig B. Titanium dioxide nanoparticles increase inflammatory responses in vascular endothelial cells. Toxicology. 2013;306:1-8. doi:10.1016/j.tox.2013.01.014
13. Montiel-Dávalos A, Ventura-Gallegos JL, Alfaro-Moreno E, et al. $\mathrm{TiO}_{2}$ nanoparticles induce dysfunction and activation of human endothelial cells. Chem Res Toxicol. 2012;25(4):920-930. doi:10.1021/tx200551u

14. Alinovi R, Goldoni M, Pinelli S, et al. Oxidative and pro-inflammatory effects of cobalt and titanium oxide nanoparticles on aortic and venous endothelial cells. Toxicol In Vitro. 2015;29(3):426-437. doi:10.1016/j.tiv.2014.12.007

15. Park J, Bauer S, Schmuki P, von der Mark K. Narrow window in nanoscale dependent activation of endothelial cell growth and differentiation on $\mathrm{TiO}_{2}$ nanotube surfaces. Nano Lett. 2009;9(9):3157-3164. doi:10.1021/nl9013502

16. Ge SN, Chen JY, Leng YX, Huang N. Laminin immobilized on titanium oxide films for enhanced human umbilical vein endothelial cell adhesion and growth. Key Eng Mater. 2007;342:305-308. doi:10.4028/ www.scientific.net/KEM.342-343.305

17. Thai TP, Houghton PE, Keast DH, Woodbury MG. Ultraviolet $C$ in the treatment of chronic wounds with MRSA: A case study. Ostomy Wound Manage. 2002;48(11):52-60. PMID:12426452

18. Dodd HJ, Sarkany I, Gaylarde PM. The short-term benefit and longterm failure of ultraviolet light in the treatment of venous leg ulcers. Br J Dermatol. 1989;120(6):809-818. doi:10.1111/j.1365-2133.1989. tb01379.x

19. Hönigsmann $\mathrm{H}$, Szeimies RM, Knobler R, et al. Photochemotherapy and photodynamic therapy. In: Goldsmith LA, Katz Sl, Gilchrest BA, Paller AS, Leffell DJ, Wolff K. Dermatology in General Medicine. New York, USA: McGraw-Hill; 1999:2477-2493.

20. Elmets CA, Bergstresser PR, Tigelaar RE, Wood PJ, Streilein JW. Analysis of the mechanism of unresponsiveness produced by haptens painted on skin exposed to low dose ultraviolet radiation. J ExpMed. 1983;158:781-794. doi:10.1084/jem.158.3.781

21. Walker JG, Stirling J, Beroukas D, et al. Histopathological and ultrastructural features of dermal telangiectasias in systemic sclerosis. Pathology. 2005;37(3):220-225. doi:10.1080/00313020500033262

22. Engel A, Johnson ML, Hynes SG. Health effects of sunlight exposure in the United States: Results from the first National Health and Nutrition Examination Survey 1971-1974. Arch Dermatol. 1988;124:72-79. doi:10.1001/archderm.1988.01670010036018

23. Cassuto DA, Ancona, DM, Emanuelli G. Treatment of facial telangiectasias with a diode-pumped Nd: YAG laser at $532 \mathrm{~nm}$. J Cutan Laser Ther. 2000;2(3):141-146. doi:10.1080/14628830050516399

24. Rabe E, Breu FX, Cavezzi A, et al. European guidelines for sclerotherapy in chronic venous disorders. Phlebology. 2014;29(6):338-354. doi:10.1177/0268355513483280

25. Landthaler M, Hohenleutner U. Laser therapy of vascular lesions. Photodermatol Photoimmunol Photomed. 2006;22(6):324-332. doi:10. 1111/j.1600-0781.2006.00254

26. Goldman MP, Martin DE, Fitzpatrick RE, Ruiz-Esparza J. Pulsed dye laser treatment of telangiectases with and without subtherapeutic sclerotherapy: Clinical and histologic examination in the rabbit ear vein model. J Am Acad Dermatol. 1990;23(1):23-30. doi:10.1016/01909622(90)70180-p

27. Apfelberg DB, Maser MR, Lash H, White DN, Flores JT. Use of the argon and carbon dioxide lasers for the treatment of superficial venous varicosities of the lower extremity. Lasers Surg Med. 1984;4:221-232. doi:10.1002/Ism.1900040302

28. Spendel S, Prandl EC, Schintler MV, et al. Treatment of spider leg veins with the KTP $(532 \mathrm{~nm})$ laser: A prospective study. Lasers Surg Med. 2002;31(3):194-201. doi:10.1002/lsm.10088

29. Thiruvenkatachari R, Vigneswaran S, Moon IS. A review on UV/TiO 2 photocatalytic oxidation process. Korean J Chem Eng. 2008;25(1):64-72. doi:10.1007/s11814-008-0011-8

30. Matthews RW, McEvoy SR. Photocatalytic degradation of phenol in the presence of near-UV illuminated titanium dioxide. JPhotochem Photobiol. 1992;64(2):231-246. doi:10.1016/1010-6030(92)85110-G

31. Li PG, Yue PL. Photocatalytic oxidation of chlorophenols in single component and multicomponent systems. Ind Eng Chem Res. 1999; 38(9):3238-3245. doi:10.1021/ie9807598

32. Emerson JA, Whittington JK, Allender MC, Mitchell MA. Effects of ultraviolet radiation produced from artificial lights on serum 25 -hydroxyvitamin D concentration in captive domestic rabbits (Oryctolaguscuniculi). Am J Vet Res. 2014;75(4):380-384. doi:10.2460/ajvr.75. 4.380 
33. Lansdown ABG, Taylor A.Zinc and titanium oxides: Promising UV-absorbers but what influence do they have on the intact skin? Int J Cosmet Sci. 1997;19(4):167-172. doi:10.1111/j.1467-2494.1997.tb00180.x

34. Galvão LEG. Terapia fotodinâmica com luz do dia: benefício clínico e estético com sessões repetidas para ceratoses actínicas faciais. Surg Cosmet Dermatol. 2016;8(4):40-42. doi:10.5935/scd1984-8773. 201683103
35. Wan MT, Lin JY. Current evidence and applications of photodynamic therapy in dermatology. Clin Cosmet Investig Dermatol. 2014;7:145-163. doi:10.2147/CCID.S35334 